\title{
Self-referral and kickbacks: fiduciary law and the regulation of "trafficking in patients"
}

\author{
Moe Litman
}

ß See related article page 1115

I $\mathrm{n}$ this issue, Sujit Choudhry and colleagues argue persuasively for comprehensive regulation of the unsavoury practices of kickbacks and self-referrals involving physicians. ${ }^{1}$ These practices are capable of corrupting clinical judgement by diverting physicians, wittingly or inadvertently, from what ought to be their exclusive preoccupation: the well-being of their patients. ${ }^{2}$ There is some evidence that clinical judgement is affected by the practice of self-referral. ${ }^{3,4}$ Self-referral creates increased costs for the health care system, ${ }^{3,4}$ and suspicions have been raised that it can not only spawn unnecessary care but also lower the quality of care. ${ }^{5}$ As in other fields, ${ }^{6}$ kickbacks have long been regarded as improper within medicine; the 1938 revision of the CMA Code of Ethics declared the "trafficking in patients," implied by "secret commissions" for patient referrals, to be "entirely unethical."

Given that there is no evidence that self-referral and kickbacks are beneficial to the health care system or to patients, the case for prohibiting them is compelling. The integrity of and public confidence in the medical profession is at stake. Regulators should take seriously Choudhry and colleagues' specific recommendations to preclude physicians from both receiving and giving kickbacks, and to ban self-referrals to family-owned "independent" health facilities. ${ }^{1}$ Interestingly, fiduciary law already precludes these practices, but Choudhry and colleagues assume that some physicians are deftly dodging this body of law.

The fiduciary duty of physicians is well established in law, ${ }^{8,9}$ but the underlying principles and legal content of this duty are anything but banal. Fiduciaries are "obligatory altruists." ${ }^{10}$ They must selflessly, although not without remuneration, attend to their patients' interests with singleminded attention. ${ }^{11}$ In law, physicians are fiduciaries because they undertake to dedicate themselves to their patients, who have a reasonable expectation of such dedication, and patients rely on it implicitly. ${ }^{11}$ Factors that give rise to the fiduciary duty of physicians include the power and influence of physicians, ${ }^{11,12}$ the vulnerability and dependence of patients ${ }^{11}$ and the solemn pledge of physicians to act only in their 2 patients' interests. ${ }^{9}$ Fiduciary duty mandates exemplary relational behaviour and, unlike malpractice law, is not concerned with standard-of-care issues. As fiduciaries, physicians must discharge their responsibilities to patients with loyalty, honesty, candour and good faith, all the while avoiding conflict of interest. ${ }^{9}{ }^{13}$ Material interests that compete with the interests of patients, including benefits of self- referrals and kickbacks, must be avoided, for they give rise to a "reasonable possibility of mischief." ${ }^{14}$ Given the comprehensive breadth of fiduciary law (even payers in kickback schemes are exposed to liability for "participating and benefiting from a breach of fiduciary duty" ${ }^{\prime 15}$ ), why is further regulation warranted?

Choudhry and colleagues' explanation is that fiduciary duty can be sidestepped by virtue of the fact that Canadian courts accept that disclosure "fulfills" fiduciary duty. ${ }^{1}$ Case law supports this assertion, although the courts also accept that caution should be exercised by physicians who are inclined toward the disclosure strategy. ${ }^{11,12}$ I have argued elsewhere that conflict of interest is "cured" by the free and informed consent of patients, not by the mere disclosure of conflicts to patients. ${ }^{11}$ Disclosure can sometimes amount to consent in law, but the realities of disclosure are such that this ought rarely to be the case. Choudhry and colleagues doubt the "effectiveness" of disclosure: patients, they point out, might misconstrue disclosures as endorsements of referrals and, also, might acquiesce to referrals to avoid straining their relationship with their physicians. ${ }^{1}$

There are other difficulties. Proper disclosure must be "full, frank and timely." the conflict - that is, the economic value to the physician of the entire impugned referral practice, and not just of the individual referral - must be divulged. ${ }^{11}$ Disclosure must be sufficiently ample to permit patients to "realistically assess the risk posed to them by the divided loyalties of their fiduciaries." In addition, the core duties of loyalty and good faith may impel fiduciaries, who collaterally benefit from referrals, to provide alternative referrals. Courts take the requirements of proper disclosure seriously. In some cases, disclosure by fiduciaries have been rendered legally ineffectual because those receiving advice were not sent for an "independent" opinion. ${ }^{16}$ Hence, the disclosure strategy is a minefield of problems and might not be a practical or reliable basis for physicians to circumvent the strictures of fiduciary law.

Although fiduciary law remains relevant after disclosure of conflict of interest, self-referral and kickback practices should nonetheless be prohibited by regulation. This is because fiduciary law does not ordinarily provide patients who are subjected to these practices with sufficient incentive to initiate legal proceedings. Where patients suffer no harm from a referred service (and in most cases patients would not suffer harm) the economic benefit of a successful fidu- 
ciary law suit is at best minimal, in the absence of unusual circumstances. ${ }^{17}$ In the absence of harm, punitive damages could be awarded for egregious behaviour; however, this would be extremely unusual. ${ }^{7,18}$ However, if patients suffer harm from the referred service, even without malpractice, it is possible that physicians could be liable for the harm. ${ }^{11,12,17}$ Fiduciary law is capable of responding harshly to the abuse of trust. Nevertheless, Choudhry and colleagues are right. Self-referral and kickback practices are ethically wrong, do a disservice to the medical system and to patients and, with few exceptions, should be banned outright.

Moe Litman is Professor of Law and Chair of the Health Law Institute, University of Alberta, Edmonton, Alta.

Competing interests: None declared.

\section{References}

1. Choudhry S, Choudhry NK, Brown AD. Unregulated private markets for health care in Canada? Rules of professional misconduct, physician kickbacks and physician self-referral. CMAF 2004;170(7):1115-8.

2. Code of Ethics of the Canadian Medical Association. Ottawa: Canadian Medical Association; 1996. Available: www.cma.ca/cma/common/displayPage.do? pageId=/staticContent/HTML/N0/12/where_we_stand/1996/10-15.htm (accessed 2004 Mar 1).

3. Mitchell JM, Sunshine JH. Consequences of physicians' ownership of health care facilities: joint ventures in radiation therapy. NEngl f Med 1992;327(21):1497-501.

4. Wilkinson P. "Self referral": a potential conflict of interest. BM7 1993;306: $1083-4$

5. Rep. Stark blasts pro-fraud proposal to gut self-referral law; introduces legislation to streamline, simplify statute [news release]. 1999; July 28. Available: www.house.gov/stark/documents/106th/selfreferpress.html (accessed 2004 Mar 1).

6. Lister \& Co. v. Stubbs (1890) 45 Ch D 1 (CA).

7. Revised Code of Ethics adopted by the Canadian Medical Association 7une 21, 1938. Toronto: The Association; 1939. p. 30.

8. Norberg v. Wynrib [1992] 2 SCR 226.

9. McInerney v. MacDonald [1992] 2 SCR 138 at para 19, 93 D.L.R. (4th) 415 (QL).

10. Birks P. The content of fiduciary obligation. Isr Law Rev 2000;34 :3.

11. Litman M. Fiduciary law and for-profit and not-for-profit health care. In Caulfield TA, von Tigerstrom B, editors. Health care reform and the law in Canada: meeting the challenge. Edmonton: University of Alberta; 2002. p. 85-130.

12. Johnston K. Patient advocates or patient adversaries? Using fiduciary law to compel disclosure of managed care financial incentives. San Diego Law Rev 1998;35:951-92.

13. Penner JE. The law of trusts. 2nd ed. London: Butterworths; 2000. p. 20.

14. MacDonald Estate v. Martin [1990] 3 SCR 1235.

15. Litman $M$, Sheremeta $L$. The report of the committee of inquiry on the case involving Dr. Nancy Olivieri: a fiduciary law perspective. Health Law Rev 2002;10(3):3-13.

16. Day v. Meade [1987] 2 NZLR 443 at $448,459 \& 468$

17. Henderson v. Fohnston [1956] 5 DLR (2d) 524 at 534 (Ont HC).

18. Whiten v. Pilot Insurance Co. (2002) 209 DLR (4th) 257 (SCC).

Correspondence to: Dr. Moe Litman, Associate Dean (Academic), 4th floor, Health Law Institute, University of Alberta, 91 University Campus NW, Edmonton AB T6G 2H5; mlitman@law.ualberta.ca

\section{The Special Bursary for Aboriginal Medical Students and \\ The Dr. John Big Canoe Memorial Scholarship - 2003/2004}

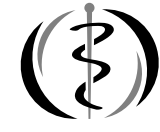

The Canadian Medical Foundation

La Fondation médicale canadienne

\section{Édition 2003-2004 de la Bourse spéciale pour les étudiants autochtones en médecine et de la Bourse commémorative $\mathrm{D}^{\mathrm{r}}$ John-Big-Canoe}

The Canadian Medical Foundation offers the Special Bursary Program for Aboriginal Medical Students and the Dr. John Big Canoe Memorial Scholarship, in an effort to reduce the inequalities in the health status of Canada's aboriginal people. These programs are open to undergraduate aboriginal medical students enrolled in a Canadian school of medicine.

The Bursary program provides financial support during medical training up to a maximum of $\$ 4000$ per academic year. A scholarship of $\$ 2000$ is also offered based on the student's academic performance and outstanding contributions to the aboriginal comamunity in Canada.

Guidelines and applications for these awards will be distributed to medical schools, aboriginal organizations and others interested in aboriginal issues and will be posted on our web site at www.medicalfoundation.ca. For further information you may contact The Canadian Medical Foundation by phone at 1-800-267-9703 ext. 2291 or by email at info@medicalfoundation.ca.

Please note the deadline for applications and supporting documentation for the $2003 / 2004$ academic year is April 14, 2004.
La Fondation médicale canadienne offre le Programme de bourses spéciales pour les étudiants autochtones en médecine et la Bourse commémorative $\mathrm{D}^{\mathrm{r}}$ John-Big-Canoe afin de contribuer à réduire les inégalités dans l'état de santé des Autochtones au Canada. Ces programmes sont ouverts aux étudiants autochtones inscrits au premier cycle dans une faculté de médecine du Canada.

Le Programme de bourses offre, pendant les études de médecine, une aide financière qui peut atteindre $4000 \$$ par année scolaire. La Fondation offre aussi une bourse de 2000 \$ fondée sur les résultats scolaires de l'étudiant et sur ses contributions exceptionnelles à la communauté autochtone du Canada.

Les lignes directrices et les formules de demande pertinentes seront distribuées aux facultés de médecine, aux organisations autochtones et à d'autres intervenants qui s'intéressent aux questions autochtones. Elles seront aussi affichées sur notre site web, à l'adresse www.fondationmedicale.ca. Pour obtenir plus de renseignements, prière de communiquer avec la Fondation médicale canadienne, par téléphone au 1-800-267-9703, poste 2291, ou par courriel à l'adresse info@fondationmedicale.ca.

Veuillez noter qu'il faut présenter au plus tard le 14 avril 2004 les demandes et les documents d'appui pour l'année scolaire 2003-2004. 